\title{
Consumer behavior of bread and its influence on "Supply Chain Management" an innovative approach
}

Paulo Sergio Gonçalves de Oliveira ${ }^{1,2}$, Jeremias Araújo ${ }^{3}$, Alexandre Faro Kaperavicsuz², Luciano Ferreira da Silva ${ }^{4}$, Fabio Airton Bandero ${ }^{3}$

${ }^{1}$ Colaborate Resercher, São Paulo, SP, Brazil.

${ }^{2}$ Anhembi Morumbi University, Post-Graduation Program in Hospitality, São Paulo, SP, Brazil.

${ }^{3}$ Anhembi Morumbi University, São Paulo, SP, Brazil.

${ }^{4}$ Nove de Julho University, Post-graduation Program in Project Management, São Paulo, SP, Brazil.

How to cite: Oliveira, P.S.G., Araújo, J., Kaperavicsuz, A.F. et al. (2020), “Consumer behavior of bread and its influence on "Supply Chain Management" an innovative approach", Brazilian Journal of Operations \& Production Management, Vol. 17, No. 4, e20201053. https://doi.org/10.14488/BJOPM.2020.045

\begin{abstract}
Goal: The paper sought to describe factors contributing to the changes in consumers' habits of processed bread since there was a tendency in the search for a whole grain meal and relating these factors with Supply Chain Management.

Design / Methodology / Approach: Aiming to achieve the study objective, and a survey with whole bread consumers were done, with 155 consumers of processed bread through a questionnaire sent by google forms using a snowball sample. A factor analysis was applied, with the model' quality measured by the KMO test, which reached a value of 0.888 , which is considered very good.

Results: The solution presented a six-factor solution, which was kept after Cronbach's Alpha analysis. The six factors are product availability, nutritional quality, product development, information search, purchase decision based on product development, and willingness to pay.

Limitations of the investigation: The study applied exploratory factor analysis to obtain the results and, therefore, is one of the paper limitations mainly because the correlations among the factors were not studied, which can be done by future researchers.

Practical implications: The model proposed by this study will guide companies and researchers to understand what can be done to improve consumer acceptance, how they can improve the production chain, aiming to develops products more suited to the customer's needs.

Originality / Value: The originality of the research is because it analyzes the consumer behavior of processed food, to capture the changes that are taking place in the market, to use the supply chain, allowing manufacturers to meet demands faster, through the use of innovations created by a supply chain integration.

Keywords: Consumer Behavior; Food and Beverage Management; Supply Chain Management; Whole Bread.
\end{abstract}

\section{INTRODUCTION}

Wheat is one of the main cereals in the diet of a large part of the world population, according to Meziani et al. (2012), and makes an essential contribution to human health. For decades, bread has been a significant component of the diet, with wheat being the most crucial cereal in bread. Therefore, in some world regions uses rye is widely considered, as well as other grains, to a lesser extent.

Financial support: Conselho Nacional de Desenvolvimento Científico e Tecnológico - Grant Number 431786/2018-6.

Conflict of interest: The authors have no conflict of interest to declare.

Corresponding author: psgoliveira@hotmail.com

Received: 31 July 2020

Approved: 9 Sep 2020

Editor: Osvaldo L. G. Quelhas. 
The estimated annual global production in 2012 was 672 million tons, is widely consumed in the form of various products, mainly bread, being the largest source of nutrients for human consumption (Bader et al., 2018), already in 2018, 733.414 million tons consumed.

Despite the high consumption of bread based on wheat flour, in recent years, there has been a change in eating habits that have led to an increase in the use of whole wheat flour in the search for a healthier lifestyle, as this type of flour considers grinding process all the essential parts of the grain (Wilson and Dahl, 2011).

This increase interferes in the bread production chain and the industry's demand for investment in innovation and the supply chain (Dalla Corte et al., 2015).

The change in bread consumer habits is mainly due to a greater awareness of the population and also due to studies that demonstrated that protein and fat derived from plants, including wholegrain bread, were associated with a lower mortality rate, suggesting that food source significantly modifies the association between carbohydrate intake and mortality (Seidelmann et al., 2018).

Therefore, this change in consumer behavior makes the industry need to capture these new consumer demands to develop, adapt, or improve their products, using consumer behavior studies.

Based on this context, this research aims to answer the following problem question: "What factors contribute to the change in habits of consumers of industrialized bread?" Therefore, the main objective will be to describe the factors contributing to changes in consumers' habits of processed bread, industrialized food, and how these factors are related to supply chain management.

Thus, the research is composed of a theoretical framework dealing with the wheat industry in Brazil and the world and Supply Chain Management. The following are the methodological procedures that allow understanding of how the research results have arrived. Finally, the field research developed the exploratory factor analysis results that will lead to the final considerations.

\section{THEORETICAL BACKGROUND}

This section presents information about the wheat production chain in Brazil and worldwide.

\subsection{The Wheat Industry in Brazil and the World}

Back demonstrates the importance of wheat in food culture; a brief historical reflection on its cultivation is presented here, in the most different cultures and times, moreover what roles this product has been assuming over time in human food (Associação Brasileira das Indústrias do Trigo, 2019).

In Brazil, the culture of wheat was introduced in 1534, by Martin Afonso de Souza, who brought it from Portugal, making the South region, due to the climate, the primary producer of the grain, which accounts for about $90 \%$ of the production of all the country. In this sense, the states of Rio Grande do Sul and Parana lead the Brazilian demand, which is insufficient for their needs (Kehl, 2013).

Wheat occupies the third place in production volume, in Brazil this annual production varies between 5 and 6 million tons having as cultivation areas the southern regions (RS, SC, and PR), Southeast (MG and SP), and Midwest (MS, GO, and DF).

Figure 1 shows the structure of wheat flour production in the mills:

After dealing with the wheat industry in the world and Brazil, it is necessary to understand how to manage the supply chain. However, before discussing this supply chain, it is essential to understand this activity more broadly, which will present the next section.

\subsection{Supply Chain Management}

To better understand the supply chain, it is essential to return to the concept that defines the value of logistics for the customer. According to Ballou (2006), logistics is vital because it 
creates value for a company's customers and suppliers and builds value for other company stakeholders. The value in logistics comprises in terms of time and place (Moori and Zilber, 2003).

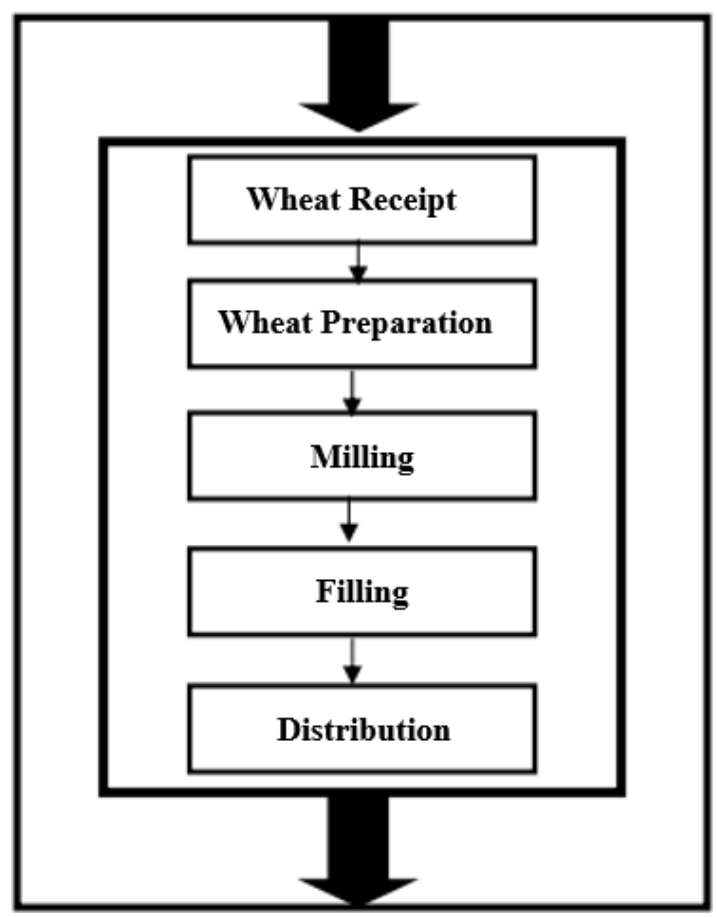

Figure 1 - Production Structure at the Mills

Source: De Oliveira (2007).

Due to the challenges presented concerning the delivery of products and services, collaboration and sharing of practices among the different agents are essential to distribute products more efficiently, especially in cities, to reduce the time and environmental impacts on society (Moori and Zilber, 2003). The supply chain also can create innovation through shared practices among enterprises (Faghat et al., 2020; Yunus, 2018).

For Paulraj and Chen (2007), SCM (Supply Chain Management) can be defined as a set of operations and approaches used to integrate suppliers, manufacturers, warehouses and warehouses, so that the goods are yielded and distributed in the right quantity, for the right location and at the right time (Shi et al., 2019).

The supply chain concept emerged as a natural evolution of the integrated logistics concept. While the latter represents an internal integration of supply, production, and distribution activities, the supply chain represents external integration, including a series of business processes that connect suppliers, industries, customers, and final consumers (Ballou, 2006).

Regarding the end customer and the process of adding value, the availability of the product at the point of sale in conditions suitable for consumption is essential. In this sense, Gurgel (2007) mentions that in the supplier-customer chain, marketing packaging aims at better product presentation and protection. Besides, it is recognized that the information must be clear, the product well presented, differentiated, and with its content visibly preserved.

In Brazil, due to its continental characteristics, the flow of production has a significant impact on the final price of agricultural commodities and, consequently, on food costs.

Transport is the activity responsible for the flows of inputs, raw materials, and finished products between all supply chain links. However, as shown in Figure 2, the consumer is the source of information and destination. 


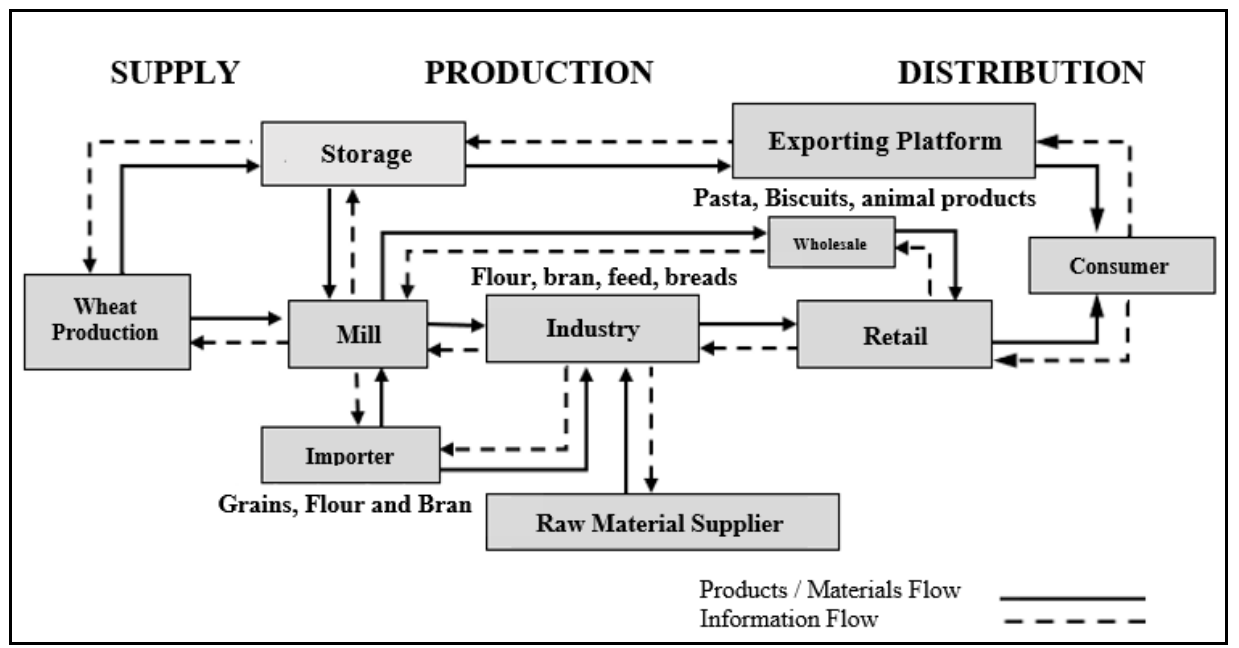

Figure 2 - Wheat Supply Chain

Source: Companhia Nacional de Abastecimento (2017)

The high managerial complexity, the excessive use of assets, and the management under a significant physical displacement of products make transportation the most extensive individual account of logistical costs, which provides business opportunities and expansion of markets. Brazil has a high degree of productive self-sufficiency in its population's main foods, except for the consecrated dependence on wheat imports.

\subsection{Bread Consumer Behavior}

Bread is becoming one of the most consumed foods in the world. However, its daily consumption varies from country to country and from individual to individual. Still, its importance in human nutrition is unquestionable, mainly because it is an excellent source of nutrients, proteins, vitamins, and minerals (Padamavathy and Murugananthi, 2007).

However, regarding food, which includes bread consumption, consumer behavior has undergone significant changes in the last decade. This situation arises mainly from the fact that consumers become more demanding in searching for healthier and better-quality foods (Gineikiene et al., 2016).

This problem is not exclusive for rich countries but is also experienced by countries with late development, as the bakery industry in most countries is of great importance (Padamavathy and Murugananthi, 2007).

This market's importance is recognized worldwide, making the need to adjust the industry to the needs of the market increasing, since less healthy diets and product prices strongly influence consumer decisions (Tsai et al., 2018).

Consumer behavior is a decision-making process in a purchasing process and in choosing market offers. However, it is essential to realize that this behavior is structured and logical and based on a series of factors that influence this process: cultural, social, biological, personal, and situational.

In this sense, according to Baccega (2008) and Neulinger et al. (2020), when consumers see that health problems have been caused by eating problems, they change their consumption process, for example, when they start to eat whole grain bread.

This market's importance is recognized worldwide, making the need to adjust the industry to the needs of the market increasing, since less healthy diets and product prices strongly influence consumer decisions (Tsai et al., 2018).

Consumer behavior is a decision-making process in a purchasing process and in choosing market offers. However, it is essential to realize that this behavior is structured and logical and based on a series of factors that influence this process: cultural, social, biological, personal, and situational. 
According to Blackwell et al. (2001) and He et al. (2019), this buying behavior is driven by objectives that the consumer must solve a need or desire. These same authors divide the purchase process into different moments, such as recognizing the need to obtain the good or service, searching for information about the desired offer, and evaluating the alternatives offered to satisfy the need or desire, purchase, evaluation post-purchase, and finally, disposal. Figure 3 describes the consumer purchase decision process (Samara and Morsch, 2004).

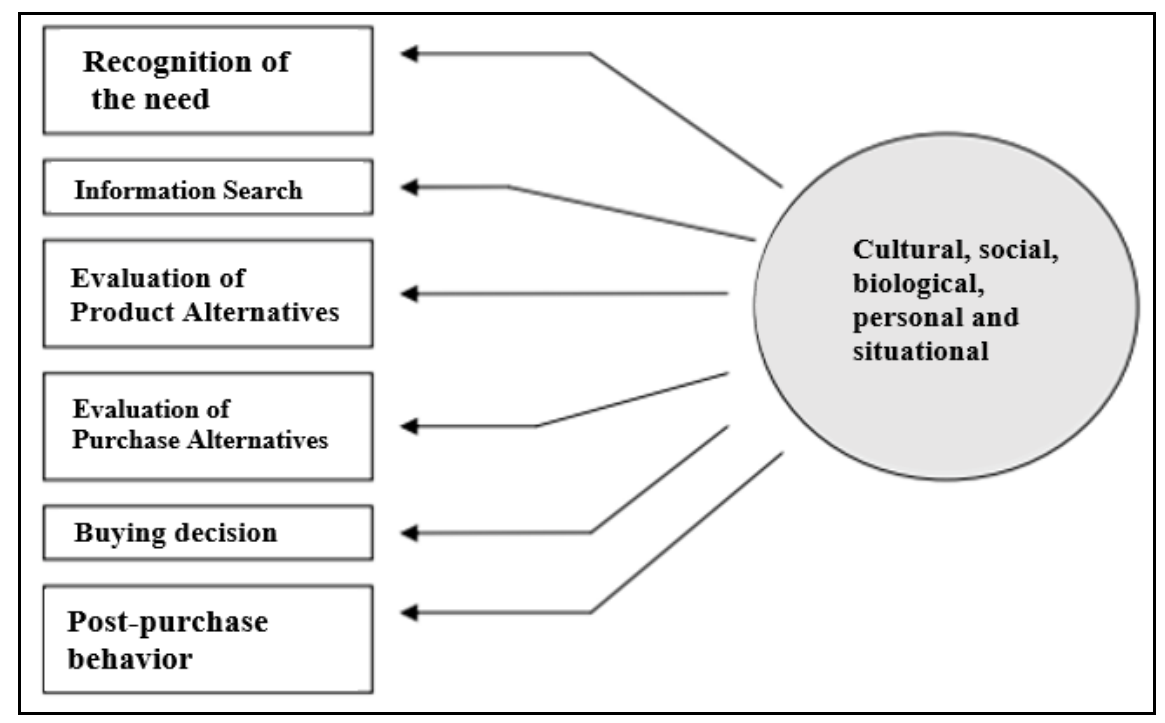

Figure 3 - The consumer purchase decision process Source: Sâmara and Morsch (2005, p. 22).

Yu-Chin Chen (2010) stated that many researchers had studied the alternatives, taste preferences, and psychometric aspects separately, studying extensively only the behavior of the client's choice, in a variety of fields, being valuable in a different way, integrated for several domains, mainly logistics and supply chain.

An element that must be evaluated when discussing consumer behavior today is the Internet, which has become an essential source of information search, education, communication, and information sharing, making the current consumer more demanding (Bhardwaj and Rani, 2018).

Thus, with the increase in informed consumers, there is a tendency to seek price and knowledge about the products (Clemons, 2008).

The development of products nowadays, with the inclusion of the bakery industry, involves a great deal of integration of the supply chain, to understand the demand, perceive problems, and propose product solutions more suited to the needs of customers, responding more quickly to needs market, enabling companies to remain competitive (Schoenherr et al., 2014).

Based on these factors, the International Association of Manufacturing in the Food Service Sector focuses on studies on the aspects that influence consumer behavior to determine how they make their choices and how companies can prepare their supply chain to develop products suited to these choices (Oberkfell, 2018).

One of the significant advantages of involving the supply chain during the development of new products is that it generates managerial flexibility by learning customers' needs, allowing bakery companies to adapt to market policies and individual needs (Lewis, 2005).

In this process, essential aspects must be considered with the customers' behavior, and changes that occur gradually, but that impact this process. Regarding the tendency to improve the quality of food (Trindade and Perez, 2013), they point out that modern individuals seek a healthier lifestyle, expanding the concept of well-being.

There is a search for products from the bakery industry that are whole (bread) and the inclusion of grains, which can satisfy consumers' tastes and be health benefits (Mullaney, 2012). 
These aspects are determined and influenced, which is why Marketing theorists call Factors that influence consumer behavior, shown in Figure 4.

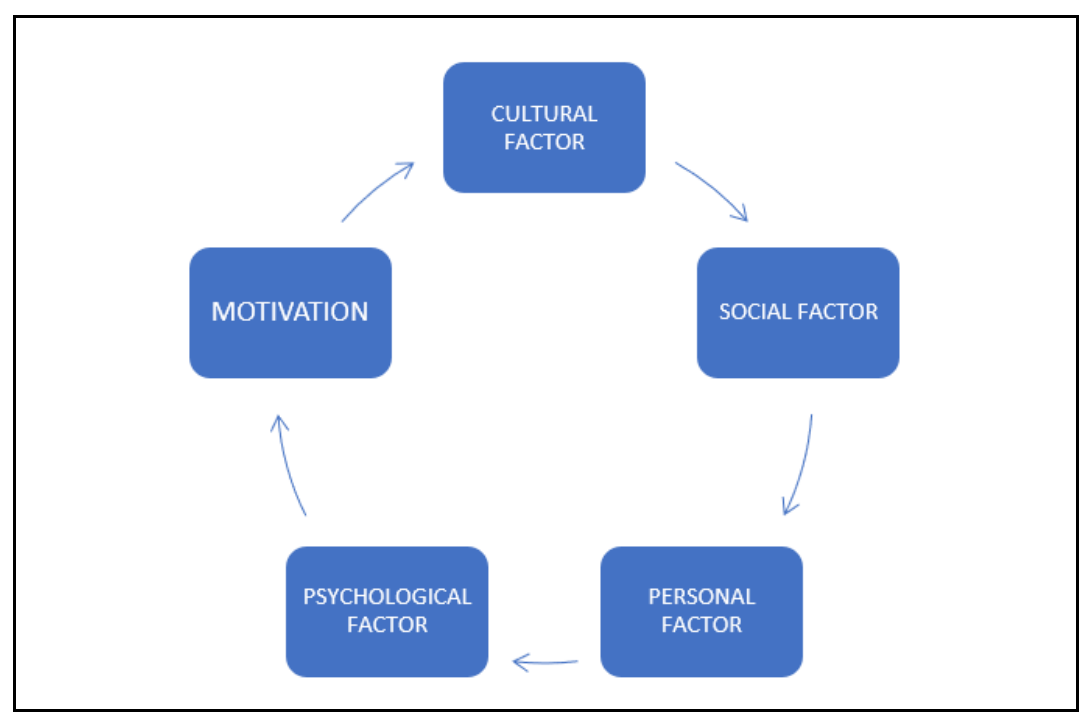

Figure 4 - Cycle of factors in the purchase decision Source: Kotler and Keller (2006)

The cycle involves cultural factors - habits and customs present in a given group of consumers; social - the pressure exerted by society for clients to behave in specific ways; personal - the cycle that people go through during their life, which is modified in each of the phases; psychological - related to motivational processes in making purchase decisions (Kotler and Keller, 2006). The next section presents the procedures used to develop the study to achieve the objective of analyzing the factors that influence the consumption of wholegrain bread because of this.

\section{METHODS}

The research sought to describe why a portion of the population consumes whole grain bread, trying to determine to what extent the research instrument's variables are related to each other.

The research level is classified by Gil (2008) on three levels: exploratory, descriptive, and explanatory. Following this model, the developed research was done in two interdependent phases: the exploratory phase and the second the descriptive one.

Exploratory research was necessary since the subject is little studied, and there are few sources of research aiming at the development of an overview (Gil, 2008). This research was applied to develop the literature review, which allowed the research instrument development. After the research instrument validation, it was sent to a group of specialists to verify their consistency.

After that, descriptive research was carried out with the primary objective of describing the characteristics of the population or the phenomenon that studied, allowing the establishment of relationships between the study variables (Gil, 2008). The descriptive research's main objective was to organize the information related to the studied subject, facilitating understanding the data (Kerlinger, 1988). To the research's descriptive stage, factor analysis was applied, aiming to describe and summarize the researched sample characteristics, which allowed to develop an analysis among the findings and the literature.

To this end, a questionnaire was developed, which was developed from the operational definition, following a series of steps, focusing on obtaining a measure of the phenomenon (Selltiz et al., 2007). 
The data gathered with an Intersectional Survey was performed, allowing the careful application of logical thinking, thus allowing the transparent and rigorous elaboration of a model (Babbie, 1999).

The universe of research comprises supermarket customers who bought wholegrain bread in the last six months (Babbie, 1999).

Regarding the satisfactory sample, the recommendation of Hair et al. (2009), which recommends that the number of respondents should be at least five times greater than the number of variables to be analyzed.

The collected data were submitted to exploratory factor analysis (EFA), which can define as a set of multivariate techniques, which aim to find an underlying structure in a data matrix, focusing on the search for determining relationships between factors without deciding to what extent (Pestana and Gageiro, 2013).

\section{DATA ANALYSIS AND OUTCOME DISCUSSION}

The research age range of the respondent's sample was comprised by about $33 \%$ Between 36 and 43 years old, 18\% Between 18 and 21 years old, $18 \%$ between 22 and 27 years old, $17 \%$ between 28 and 35 years old, $13 \%$ between 44 and 50 years old and $12 \%$ with age above 51 years old. The majority of then, about $90 \%$, have higher education and postgraduation, and only about $10 \%$ have a fundamental course.

As for incomes, about $65 \%$ received wages between BRL $\$ 1.001,00$ and BRL $\$ 5.000,00$, about $27 \%$ received wages above $B R L \$ 5.000,00$, and only $8 \%$ received wages below BRL $\$ 1.000,00$.

After a brief description of the respondent's profile, the factor analysis was performed by the method of extraction of the main components and Rotation by the Varimax Method and suppression of 0.489. The initial factor extraction with the cutoff points was demonstrated in Figure 5:

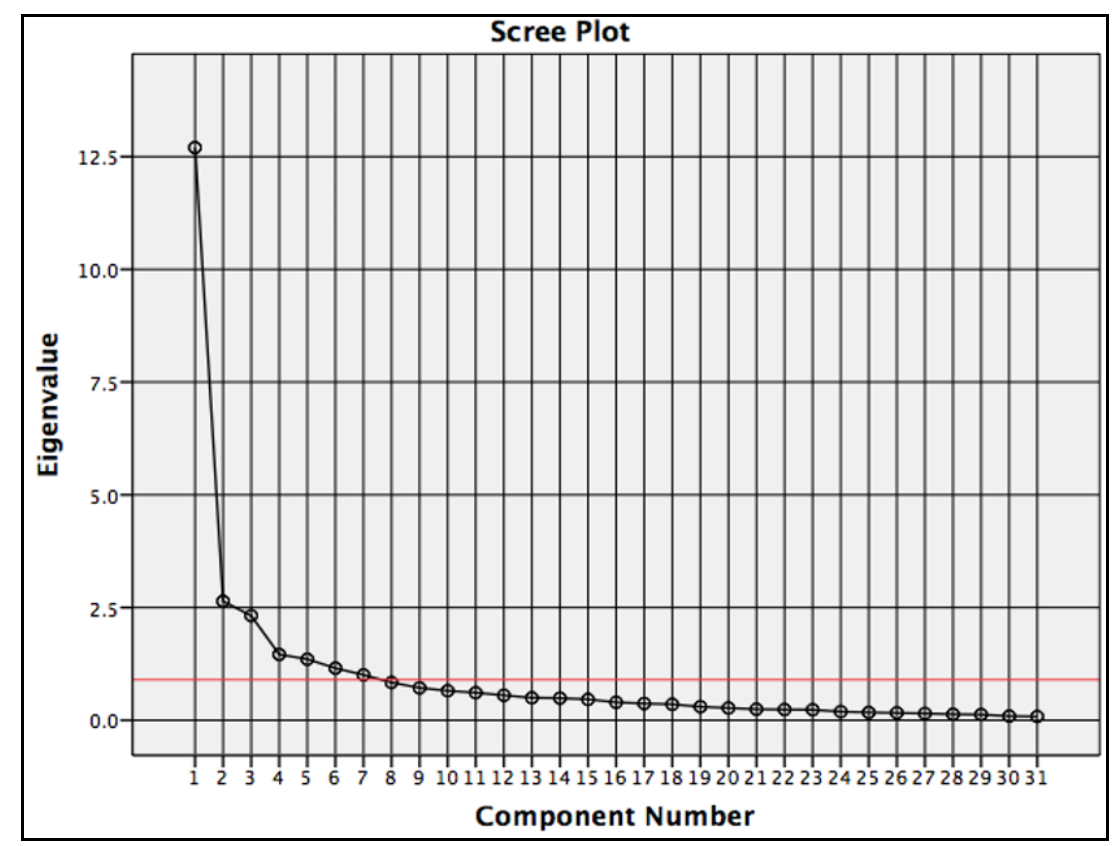

Figure 5 - Scree Plot with Factor Cutoff Point

Source: This figure was elaborated using the data collected and analysed

The initial solution had seven factors, but it was necessary to eliminate variable 13 , as it presented very similar loads in 4 factors (Factor $1=>0.464$, Factor $2=>0.448$, Factor $3=>0.351$ and Factor $4=>0.411$ ); for the same reason, variable 17 was also eliminated, for presenting similar loads (Factor $1=>0.477$, Factor $2=>0.362$, Factor $4=0.423$ and Factor $5=0.337$ ); finally, variable 26 was also eliminated for presenting similar loads in 2 factors (Factor $2=>0.586$ and Factor $6=>0.583$ ). 
The final model presented a solution comprised of six factors submitted to quality analysis and factor adequacy for the research development. The sample consisted of 155 respondents who should respond to the survey's statements according to their degree of agreement, considering the questions on the Likert scale values ranging from 1 to 7 , where one corresponds to "totally disagree" and seven correspondings to "I totally agree."

The study's KMO value was 0.888 , which is considered "Very Good," according to the criteria pointed out by Pestana and Gageiro (2013), indicating that the factor analysis is adequate for data analysis it can proceed to the study. The second test used was the Bartlett sphericity test, which aimed to verify whether there are correlations between the variables, rejecting the data's null hypothesis. It is not an identity matrix; the value found can affirm that with a value of $p$ below 0.0001 , the data have correlations, with adequacy to the type of made analysis (Hair et al., 2009).

The next analysis aimed at verifying the model's quality was the sample adequacy measure, through the anti-image matrix, which, according to Hair et al. (2009), is the measure of Intercorrelations between variables.

Values considered acceptable for this type of analysis must be above 0.05 ; those below the value are unacceptable. The outcome found in the study was above the recommended threshold; therefore, it is unnecessary to eliminate any variable (Hair et al., 2009; Pestana and Gageiro, 2013).

The subsequent analysis to assess data quality was the analysis of communalities, which according to Hair et al. (2009), represents the total variance that the original variable shares with the others, being a measure of acceptance values above 0.5 . In this analysis, all results were also above the recommended.

The next analysis explained variance, which, for a 6 -factor solution, reached an explanation of 70\%; other factors explain the remaining $30 \%$. Thus, functional data adequacy was observed with this solution. The next analysis was the explained variance, which, for a 6factor solution, reached an explanation of $70 \%$. The remaining $30 \%$ is explained by other factors, thus observing the data's functional adequacy through this solution (Pestana and Gageiro, 2013).

The last model quality analysis was Cronbach's Alpha, which represents a measure of reliability for each factor and varies from 0 to 1, according to Hair et al. (2009), with acceptability values being those between 0.6 and 0.7 , as lower limits. The study values were demonstrated in table 1.

Table 1 - Cronbach's Alpha of Factors

\begin{tabular}{ccc}
\hline Factor & Cronbach's Alpha & Number of Variables \\
\hline 1 & 0.915 & 8 \\
\hline 2 & 0.898 & 6 \\
\hline 3 & 0.788 & 4 \\
4 & 0.726 & 3 \\
5 & 0.803 & 3 \\
\hline 6 & 0.782 & 3 \\
\hline
\end{tabular}

Source: This figure was elaborated using the data collected and analysed

Based on the values found in Table 1, all factors presented above the recommended by Hair et al. (2009), this reason does not need to eliminate any of the study factors. The matrix rotated with the factors found in the study was shown in Table 2. 
Table 2 - Matrix of Named Factors

\begin{tabular}{|c|c|c|c|c|c|c|c|}
\hline \multicolumn{8}{|c|}{ Rotated Matrix } \\
\hline & & \multicolumn{6}{|c|}{ Component } \\
\hline & & 1 & 2 & 3 & 4 & 5 & 6 \\
\hline \multirow{5}{*}{ 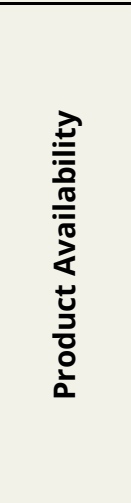 } & $\begin{array}{l}\text { "I would feel like consuming whole grain bread if: [6) were } \\
\text { available at establishments closer to my home.]" }\end{array}$ & .765 & & & & & \\
\hline & $\begin{array}{l}\text { "I would go back to consuming and/or recommend the } \\
\text { consumption of wholegrain bread: [31) If they were } \\
\text { available in more places of purchase]" }\end{array}$ & .749 & & & & & \\
\hline & $\begin{array}{l}\text { "I would buy more wholegrain bread: [18) If there was a } \\
\text { greater variety of products on market shelves]" }\end{array}$ & .693 & & & & & \\
\hline & $\begin{array}{l}\text { "I would certainly feel like consuming whole grain bread if: } \\
\text { [4) were present in different types of establishments } \\
\text { (markets, bakeries, bars, etc.)]" }\end{array}$ & .686 & & & & & \\
\hline & $\begin{array}{l}\text { "I would consume more wholegrain bread if the } \\
\text { information: [9) were available at sales points]" }\end{array}$ & .652 & & & & & \\
\hline \multirow{5}{*}{ 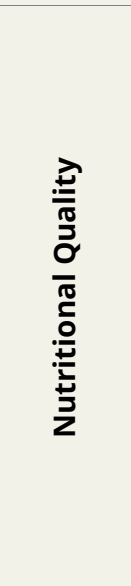 } & $\begin{array}{l}\text { "I would go back to consuming and/or recommend the } \\
\text { consumption of wholegrain bread: [29) For always finding } \\
\text { good product options]" }\end{array}$ & & .782 & & & & \\
\hline & $\begin{array}{l}\text { I would buy more wholegrain bread: [20) Because they are } \\
\text { a healthier option] }\end{array}$ & & .740 & & & & \\
\hline & $\begin{array}{c}\text { "I would go back to consuming and/or recommend the } \\
\text { consumption of wholegrain bread: [30) Because it is in line } \\
\text { with my lifestyle]" }\end{array}$ & & .735 & & & & \\
\hline & $\begin{array}{c}\text { "I would go back to consuming and/or recommend the } \\
\text { consumption of wholegrain bread: [27) Because I liked the } \\
\text { taste of the product]" }\end{array}$ & & .721 & & & & \\
\hline & $\begin{array}{c}\text { "I would go back to consuming and/or recommend the } \\
\text { consumption of wholegrain bread: [28) For better } \\
\text { controlling my hunger]" }\end{array}$ & & .692 & & & & \\
\hline \multirow{2}{*}{ 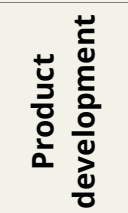 } & $\begin{array}{l}\text { "I would consume more wholegrain bread if the } \\
\text { information: [7) The packaging were clearer]" }\end{array}$ & & & .844 & & & \\
\hline & $\begin{array}{l}\text { "I would consume more wholegrain bread if the } \\
\text { information: [8) Product labels were better to understand]" }\end{array}$ & & & .818 & & & \\
\hline \multirow{2}{*}{ 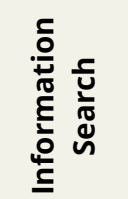 } & $\begin{array}{l}\text { "I would consume more wholegrain bread if tastings at } \\
\text { points of sale accompanied the information: [12)]" }\end{array}$ & & & & .700 & & \\
\hline & $\begin{array}{l}\text { "I would feel like consuming whole grain bread if: [3) They } \\
\text { had more options with grains, nuts, and dried fruit.]" }\end{array}$ & & & & .675 & & \\
\hline \multirow{3}{*}{ 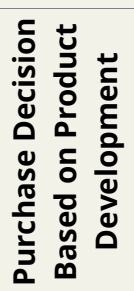 } & $\begin{array}{l}\text { "I would be better able to choose and evaluate wholegrain } \\
\text { bread if: [15) They taste better]" }\end{array}$ & & & & & .890 & \\
\hline & $\begin{array}{l}\text { "I would feel like consuming wholegrain bread if: [5) The } \\
\text { taste of these products was more pleasant]" }\end{array}$ & & & & & .872 & \\
\hline & $\begin{array}{l}\text { "I would buy more wholegrain bread: [19) If the softness of } \\
\text { the product was closer to the traditional one]" }\end{array}$ & & & & & .675 & \\
\hline \multirow{2}{*}{ 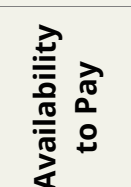 } & $\begin{array}{l}\text { I would accept to pay more for wholegrain bread: [24) For } \\
\text { the brand] }\end{array}$ & & & & & & .813 \\
\hline & $\begin{array}{l}\text { "I would accept to pay more for wholegrain bread: [23) } \\
\text { Because they are healthier]" }\end{array}$ & & & & & & .784 \\
\hline
\end{tabular}

Source: Elaborated with research data (2018)

The main advantage of factor analysis is the data reduction provided by it, allowing for a better explanation of the data (Hair et al., 2009). The results fit the model, making it possible 
to analyze the factors and establish a theoretical relation among consumer behavior studies and how logistics and the supply chain can support this process (Pestana and Gageiro, 2013).

Factor 1 was called product availability, as it has variables 4, 6, 9, 18 and 31. The outcomes presented on variable 4 - "I would feel like consuming wholegrain bread if: Were present in several types of points of sale" were about $27 \%$ marked $1,2,3$, and about $73 \%$ choose notes above 4, indicating a significant agreement about this affirmation. The variable 6 - "I would feel like consuming wholegrain bread if: They were available at establishments closer to my home." presented the following results: about $43 \%$ of the respondents answered the options $1,2,3$, and $57 \%$ marked values above 4 indicating such a balance between the first and second respondents group. The values presented on variable 9 - "I am certain consumes more wholegrain bread if the information is about them: Was available at sales points" achieve the following results: about 39\% declared this is not important for them because they marked notes among 1 to 3 about $61 \%$ marked notes above 4 , indicating the majority of the respondents agree with this affirmation.

Resuming on factor 1 outcomes about the results achieved by variable 18 - "I would buy more wholegrain bread: [18) If there was a greater variety of products on the shelves in the markets" about 30\% of the respondents agree less with this affirmative because their marked values among 1 to 3 and the majority about 70\% strongly agree with this affirmation. When comes about the results achieved by variable 31 - "I would go back to consuming and / or recommend the consumption of wholegrain breads: [31) If they were available in more places of purchase" considering the answers give by the respondents about $30 \%$ marked values among 1 to 3 and $70 \%$ marked values above 4 indicating that almost the majority strongly agree with this affirmative.

These results indicate a relation among consumer behavior studies, to predict their preference and map the supply chain structure, mainly to overcome the challenge presented by Gineikiene et al. (2016), mainly about the healthier way of life.

These aspects are linked to the supply chain's efficiency and continuous replacement through the EDI tool, currently Web EDI, and the partnership with suppliers (Raghunathan and Yeh, 2001; Hui et al., 2015).

Thus, companies should take advantage of the technologies available for cloud storage, aiming to improve the exchange of information and collaboration between partners (Yu et al., 2017).

This collaboration between partners (suppliers, customers, and employees) is vital to seek to improve the Efficient Consumer Response (ECR - Efficient Consumer Response), through the availability of products when and where the customer needs (Hanak and Dimitrijevic, 2013).

Parsa and Fisher (2002) emphasized the great importance of this factor in that companies understand the needs of consumers, aiming at the development of products, through the improvement of the supply chain, focusing on suppliers.

The findings corroborate with observed by Schoenherr et al. (2014), that one of the ways to improves products availability, is through the new varieties development, possible through of a great job the supply chain integration, allowing to respond more quickly to consumer needs, improving companies competitiveness.

Factor 2 was called "Nutritional Quality" and is linked to the consumer's search for a healthier lifestyle. With this factor in mind, the variables belonging were evaluated, first of them was the variable 20 - "I would buy more wholegrain bread: Because they are a healthier option', which the about 23\% of the respondents marked values among 1 to 3 about $77 \%$ marked values above 4 indicating the majority of them strongly agree with this affirmative. The second was the variable 27 - "I would go back to consuming and recommend the consumption of wholegrain bread: because I liked the taste of the product," where about $12 \%$ marked the options among 1 to 3 and, the majority of the respondents $88 \%$ marked values above 4, indicating the respondents strongly agree with this affirmative. 
Backing factor 2 descriptive analysis, the third variable was 29 - "I would go back to consuming and / or recommend the consumption of wholegrain bread: For always finding good product options" where about 23\% of the respondents chose values among 1 to 3 and about $77 \%$ marked values above 4 indicating the majority of them strongly agree with this affirmative. Finally, the fourth variable was 30 - "I would go back to consuming and/or recommend the consumption of wholegrain bread: Because it is in line with my lifestyle" where the outcomes were about 19\% marked values among 1 to 3 and the majority of them $81 \%$ choose values above 4 which indicates that is the majority of them strongly agree with this affirmative. These variables indicate that is factor was more linked to Consumer Behavior.

Whole grains, as highlighted by Kotler and Keller (2006), lifestyle is related to Personal Factors that influence customer behavior. It is crucial to know how to choose, buy, and discard products and services that meet customer needs.

Also, Trindade and Perez (2013) had this same perception that today's individuals have motivated to seek a healthier lifestyle by expanding the concept of well-being, especially concerning food consumption.

Thus, it appears that there is a search for products from the whole bakery (bread) industry and with the inclusion of grains, which can satisfy consumer expectations, in addition to providing additional health benefits (Mullaney, 2012).

Despite the fact this factor was more linked to Consumer Behavior, the enterprises need to pay attention to the supply chain and how and how quantity these products will be available for customers. The previous observation corroborates with Ballou (2006), where observes the logistics are vital because it creates value for a company's customers and suppliers and building value for other stakeholders of a company.

The last paragraph demonstrates the importance of integrates the consumer behavior and supply chain analyses, mainly because this two areas dependent of each other, because without marketing and consumer behavior actions, the enterprises do not know what to produce and even will have customers and if those actions were taken without a supply chain and logistics planning the enterprises do not know what produce and where the product are demanded and how the logistics and supply chain can transform this in a competitive advantage and according to Gurgel (2007) make the products available.

Following the observations, this factor is directly linked to the previous factor because, as people look for healthy foods, they must be available, only possible through the integration of the supply chain.

From a logistical point of view, a discipline that must also exercise is developing new products, intending to increase availability, and offer a broader range of options in terms of healthy products.

However, Clemons (2008) warns that companies should be concerned with offering information to consumers, as they are looking for lower prices and reliable information about products.

This aspect is essential for companies seeking to understand consumer needs and how they make their choices, integrating Marketing with supply chain management (Parsa and Fisher, 2002).

The studies corroborate the product development aspect by Schoenherr et al. (2014). They add that this aspect involves a great deal of work on integrating the supply chain through understanding the demand, which allows the perception of problems, allowing the proposition of more suitable solutions for consumers.

Factor 3 was called "Product development" keeping this factor variable outcomes in mind. The first one variable 7 concentrates about 44\% of respondents' answers among values 1 to 3 and $66 \%$ of their answers above 4 indicating that they partially agree with this affirmative. The second variable belonging to this factor was 8 - "I would consume more wholegrain bread if the information: Product labels were better understandable," were about $40 \%$ marked values among 1 to 3 , and $60 \%$ pointed out values above 4 almost agree with this affirmative. 
This factor from Marketing allows customers to understand the customer needs and drive the development of products by discovering the ways that lead the customer to make their choices, especially in bakery companies, as they claim (Parsa and Fisher, 2002). In general terms, it is how companies transform consumers' needs and desires into products or services available to the market.

Thus, one way to increase the chance of success for a new product is the active participation of the customer during the process by creating a knowledge management structure that makes it possible to capture the customers' wishes and make the product succeed. Meet most of their needs, which certainly creates a series of managerial implications for companies (Woojung and Taylor, 2016).

Nonetheless, without the supply chain involvement to integrate and coordinate the various agents involved in product development to reduce the uncertainty and create and deliver products on time and the quality, they expect this factor will present certain flaws (Zhai et al., 2017). These affirmations are corroborated by Paulraj and Chen (2007) and Ballou (2006) as an essential aspect of Supply Chain Management.

Product development is vital for a customer, and the process of adding value, the availability of the product at the point of sale in conditions suitable for consumption is essential. In this sense, Gurgel (2007) mentions that in the supplier-customer chain, marketing packaging aims at better product presentation and protection. Besides, it is recognized that the information must be clear, the product well presented, differentiated, and with its content visibly preserved.

Due to the implications presented, this factor is related to factor 2 as it demonstrates the need to capture customer needs quickly and safely, maintaining the expected quality.

Factor 4 was called "Search for information" because it is linked to the consumer purchase decision process. The outcomes found in this factor for variables were: "I would feel like consuming wholegrain bread if: They had more options with grains, nuts, and dried fruits" where about $36 \%$ of respondents marked values among 1 to 3 about $64 \%$ of them marked values above 4 indicating the respondents agree partially with this affirmative. The variable 12 "I would consume whole grain bread if the information: were accompanied by tastings at the points of sale" where about $21 \%$ marked values among 1 to 3 and about $79 \%$ marked values above 4 , indicating they strongly agree with this affirmative.

As highlighted by Kotler and Keller (2006), it is the moment after the phase in which customers perceive that they have a problem that needs to be solved, using internal, external, commercial, public, experimental, and personal research sources that moment.

This factor, in turn, is mainly supported by factors 1,2 , and 3 . As noted by Parsa and Fisher (2002), companies must seek ways to understand consumers and provide the necessary information for decision making.

It is also essential to observe the research results by Clemons (2008), which made it possible to recognize the relevance of providing companies with information for consumers, considering that they are looking for low prices, but subsidies to make the best decisions.

In the bakery industry, the search for information on the part of customers is increasing, mainly due to the issue of food quality, taking into account that people are looking for healthier food options, making it necessary to develop previous studies on the habits of consumers (Gineikiene et al., 2016).

Due to the interest in wholegrain bread that includes new grains, information provision becomes an essential ally for companies, allowing them to develop varieties of products more targeted to each group of consumers (Mullaney, 2012).

Even though consumer behavior studies are essential in this factor, this information and the actions to obtain data were only possible when enterprises invest in Supply Chain Management. Because the capability of integrating various agents through the supply chain is considered a success factor as affirmed Zhai et al. (2017) and can improve a set of operations as observed, Paulraj and Chen (2007) allow the enterprises to obtain customer information. 
About factor 5, this was called "Purchase Decision Based on Product Development," the outcomes presented by this variables were on firstly was analyzed the variable 5 - "I would feel like consuming wholegrain bread if the taste of these products was more pleasant" where about $31 \%$ of respondents marked options among 1 to 3 and about $69 \%$ marked options above 4 , indicating they strongly agree with this affirmative. On second the variable 15 - "I would be better able to choose and evaluate wholegrain bread if: they taste better" where about 22\% marked values between 1 to 3 about $78 \%$ of them marked values above 4 indicating they strongly agree with this variable.

From the organization perspective, it depends on data and information that help planning along the supply chain to develop better and more appropriate products, aligned with consumers' needs.

The purchase decision is motivated by the aspects perceived in factor 1 ; it depends primarily on the supply chain's efficiency, whose management of the information flow involves the planning and coordination of logistics operations (Christopher, 2016).

This aspect is linked to understanding consumers' needs and thus developing products more adapted to the needs of customers, as pointed out in factor 3 that aims at product development, thus generating availability. Factor 4 (Information Search) also strongly influences this factor. The customer does not seek the only price but provides information that allows them to know the product, thereby improving their purchase decision-making.

Factor 6 was named "Availability to pay," mainly because it is related to consumers looking for whole bread products that provide additional health benefits. These variables presenting the following outcomes: First of all 23 - "I would agree to pay more for wholegrain bread: because they are healthier where presented values of $32 \%$ for values marked among 1 to 3 and $68 \%$ for values above 4 which indicates the majority of them strongly agree with this affirmative. The variable 24 - "I would accept to pay more for wholegrain bread: for the brand," which presented values of 54\% for values among 1 to 3 and $46 \%$ for values above 4 , indicating most of them disagree with this affirmative.

This involvement can range from simple consultations with suppliers on design ideas to making suppliers fully responsible for designing the components or systems they will supply. Besides, suppliers may be involved in different stages of the new product development process. Early supplier involvement is a crucial coordination process in supply chain design, product design, and process design.

The majority of the aspects of this factor are linked to Supply Chain Management as observed by Paulraj and Chen (2007) and Shi et al. (2019) where they define a set of operations used to integrate suppliers, manufactures, warehouses, and enterprises to improve the distribution and product development. However, practitioners need to keep in mind that is Marketing and Consumer Behavior plays an essential role in this factor because this can obtain the factors that are important to understand the willingness of the customer to pay. This understanding was achieved by an integrative approach, as proposed by Han et al. (2017).

Several important questions about supplier involvement in new product development remain unanswered. Specifically, when looking at which management practices affect the effectiveness of the new product development team whose suppliers are involved.

Finally, it examined whether the supplier's involvement in developing new products can produce significant improvements in financial returns and/or product design performance. Thus, these proposed relationships tested using research data collected from a group of global organizations based on a multiple regression analysis.

\section{CONCLUSIONS}

The development of the present study made it possible to analyze how certain factors may impact the consumer purchase decision for wholegrain bread and, consequently, the wheat supply chain through data collection and exploratory factor analysis.

Wheat, the primary input for flour and bread, as defined, is a cereal that goes beyond symbology or another food option. It accompanies humanity for hundreds of years, with bread being one of the most consumed derivatives in the world antiquity. 
Therefore, this study did not address questions about gluten consumption and low carbohydrate diet practices. Recent scientific research has shown that a lack of carbohydrate intake can reduce an individual's life expectancy. That consumption of Whole fibers helps to improve the functioning of the intestinal flora.

In this study, the factors "search for information" and "product availability" influenced consumer behavior and can help you in your decision to consume whole grain bread.

Thus, the integration of the supply chain and its flexibility can improve the quality of the chain's links. Another factor observed was the search for a healthier life linked to the development of new products, evoking logistics' attention.

Regarding customer decision when choosing a particular wholemeal bread brand remembered or cited by the respondents, the Mexican Bimbo Group's hegemony demonstrated, which is the largest food company in Mexico and the undisputed leader in bread making in the country, as well as in several Latin American countries. In Brazil, the company commands at least three major manufacturers of wholemeal bread: Pullman, Nutrella, and, Plus Vita.

With that, the intention at the end of this study is that the result of this work will guide companies and researchers to understand what can be done to improve consumer acceptance, the production chain, and the development of products more suited to customers' needs.

\section{REFERENCES}

Associação Brasileira das Indústrias do Trigo - ABITRIGO (2019), available at: http://www.abitrigo.com.br/ (accessed 21 February 2019).

Babbie, E. (1999), Métodos de Pesquisas de Survey, Ed. da UFMG, Belo Horizonte.

Baccega, M.A. (2008), Comunicação e Culturas do Consumo, Atlas, São Paulo.

Bader, H.U.A., Saeed, F., Ahmad, N. et al. (2018), "Functional and health-endorsing properties of wheat and barley cell wall's non-starch polysaccharides", International Journal of Food Properties, Vol. 21, No. 1, pp. $1463-80$.

Ballou, R.H. (2006), Gerenciamento da Cadeia de Suprimentos/ Logística Empresarial, 5. ed., Bookman, Porto Alegre.

Bhardwaj, V.K. and Rani, M. (2018), "Effect of internet addiction in relation to healthiness and well-being in rural and urban students: comparative study", Indian Journal of Health \& Wellbeing, Vol. 9, No. 1, pp. 12-8.

Blackwell, R.D., Miniard, P.W. and Engel, J.F. (2001), Consumer Behavior, Harcourt College Publishers, San Diego.

Chen, Y.-C. (2010), “Conceptualization of incorporating subjective taste preference, subjective psychometric constructs, and objective alternative attributes into consumer choice behavior models", Social Behavior and Personality, Vol. 38 No. 1, pp. 143-144-144.

Christopher, M. (2016), Logistics \& Supply Chain Management, 5. ed., FT Press, Harlow, England.

Clemons, E.K. (2008), "How information changes consumer behavior and how consumer behavior determines corporate strategy", Journal of Management Information Systems, Vol. 25, No. 2, pp. 1340.Companhia Nacional de Abastecimento - CONAB (2017), "Acompanhamento de safra brasileiro a cultura do trigo", available at: https://www.conab.gov.br/uploads /arquivos/ 17_04_25 _11_40_00_a_cultura_do_trigo_versao_digital_final.pdf (accessed 12 January 2018).

Dalla Corte, V.F., Dabdab Waquil, P. and Stiegert, K. (2015), "Wheat industry: which factors influence innovation", Journal of Technology Management \& Innovation, Vol. 10, No. 3, pp. 11-7.

De Oliveira, M.J. (2007), Proposta de Planejamento e Controle da Produção na Agroindústria de Moagem de Trigo, Dissertação de Mestrado em Engenharia de Produção, Programa de Pós-graduação em Engenharia de Produção, Universidade Tecnológica Federal do Paraná, Ponta Grossa, PR.

Faghat, E.R.B., Khani, N. and Alemtabriz, A. (2020), "A paradigmatic model for shared value innovation management in the supply chain: a grounded theory research", International Journal of Innovation Science, Vol. 12, No. 1, pp. 142-166. https://doi.org/10.1108/IJIS-07-2019-0074.

Gil, A.C. (2008), Métodos e Técnicas de Pesquisa Social, 6. ed. , Atlas, São Paulo. 
Gineikiene, J., Schlegelmilch, B.B. and Ruzeviciute, R. (2016), "Our apples are healthier than your apples: deciphering the healthiness bias for domestic and foreign products", Journal of International Marketing, Vol. 24, No. 2, pp. 80-99.

Gurgel, F.D.A. (2007), Administraçao da Embalagem, SENAC RIO, Rio de Janeiro.

Hair, J., Anderson, R. and Babin, B. (2009), Multivariate Data Analysis, 7. ed., Prentice Hall, Upper Saddle River, NJ.

Han, S., Zhao, L., Chen, K. et al. (2017), "Appointment scheduling and routing optimization of attended home delivery system with random customer behavior", European Journal of Operational Research, Vol. 262, No. 3, pp. 966-80.

Hanak, N. and Dimitrijevic, A. (2013), "A serbian version of modified and revised experiences in close relationships scale (SM-ECR-R)", Journal of Personality Assessment, Vol. 95, No. 5, pp. 530-8.

He, Q., Duan, Y., Wang, R. et al. (2019), "Factors affecting consumers' purchase intention of eco-friendly food in China: The evidence from respondents in Beijing", International Journal of Consumer Studies, Vol. 43, No. 5, pp. 457-70.

Hui, Z., He-Cheng, W. and Min-Fei, Z. (2015), "Partnership management, supply chain collaboration, and firm innovation performance: an empirical examination", International Journal of Innovation Science, Emerald Group Publishing Limited, Vol. 7, No. 2, pp. 127-38.

Kehl, K. (2013), Potencial de Rendimento, Qualidade Industrial e Fisiológica de Sementes de Trigo Cultivado Em Diferentes Regiões Tritícolas, Dissertação de Mestrado em Ciências, Universidade Federal de Pelotas, Pelotas, RS.

Kerlinger, F.N. (1988), Metodologia da Pesquisa em Ciências Sociais. Um Tratamento Conceitual, 8. ed., EPU, São Paulo.

Kotler, P. and Keller, K.L. (2006), Marketing Management, Pearson Prentice Hall, Nova Jersey.

Lewis, M. (2005), "Incorporating strategic consumer behavior into customer valuation", Journal of Marketing, Vol. 69, No. 4, pp. 230-8.

Meziani, S., Nadaud, I., Gaillard-Martinie, B. et al. (2012), "Proteomic analysis of the mature kernel aleurone layer in common and durum wheat", Journal of Cereal Science, Vol. 55, No. 3, pp. 323-30.

Moori, R.G. and Zilber, M.A. (2003), "Um estudo da cadeia de valores com a utilização da análise fatorial", Revista de Administração Contemporânea, Vol. 7, No. 3, pp. 127-47.

Mullaney, L. (2012), Good Seed for the Day, British Baker, England, pp. 27-9.

Neulinger, A., Bársony, F., Gjorevska, N., Lazányi, O., Pataki, G., Takács, S. and Török, A. (2020), "Engagement and subjective well-being in alternative food networks: the case of Hungary", International Journal of Consumer Studies, Vol. 4, No. 4, pp. 306-315. https://doi.org/10.1111/ijcs.12566.

Oberkfell, L. (2018), "Innovation needs insight: studies eye at-home consumer", Prepared Foods, Vol. 8, No. 185, pp. $25-25$.

Padamavathy, P. and Murugananthi, D. (2007), "A study on consumer buying behavior of bread", ICFAI Journal of Consumer Behavior, Vol. 2, No. 4, pp. 66-74.

Parsa, H.G. and Fisher, R. (2002), "Consumer behavior in foodservice", Journal of Foodservice Business Research, Vol. 5, No. 2, pp. 1-3.

Paulraj, A. and Chen, I.J. (2007), "Strategic buyer? Supplier relationships, information technology and external logistics integration", The Journal of Supply Chain Management, Vol. 43, No. 2, pp. 2-14.

Pestana, M. H. and Gageiro, J. N. (2013), Analise de Dados para as Ciencias Sociais - a Complementariedade do SPSS, 5. ed., ND-Edicoes Silabo, Lisboa.

Raghunathan, S. and Yeh, A.B. (2001), "Beyond EDI: impact of Continuous Replenishment Program (CRP) between a manufacturer and its retailers", Information Systems Research, Vol. 12, No. 4, pp. 406-19.

Samara, B.S. and Morsch, M.A. (2004), Comportamento do consumidor, Pearson, Ribeirão Preto.Samara, B.S. and Morsch, M.A. (2005), Comportamento do Consumidor: Conceitos e Casos. São Paulo: Prentice Hall.

Schoenherr, T., Griffith, D.A. and Chandra, A. (2014), "Intangible capital, knowledge and new product development competence in supply chains: process, interaction and contingency effects among SMEs", International Journal of Production Research, Vol. 52, No. 16, pp. 4916-29.

Seidelmann, S.B., Claggett, B., Cheng, S. et al. (2018), "Dietary carbohydrate intake and mortality: a prospective cohort study and meta-analysis", The Lancet. Public Health, Vol. 3, No. 9, pp. e419-28. 
Selltiz, C., Wrightsman, L.S. and Cook, S.W. (2007), Metodos de Pesquisa nas Relações Sociais. Delineamentos de Pesquisa, EPU, São Paulo, Vol. 1.

Shi, Y., Lin, W., Chen, P.-K. et al. (2019), "How can the ISO 9000 QMS improve the organizational innovation of supply chains", International Journal of Innovation Science, Emerald Publishing Limited, Vol. 11, No. 2, pp. 278-98.

Trindade, E. and Perez, C. (2013), “Aspectos dos vínculos de sentidos do consumo alimentar em São Paulo: difusão publicitária e megatendências", Intercom-Revista Brasileira de Ciências da Comunicação, Vol. 36 , No. 2, pp. 245-266.

Tsai, C., Svensen, E., Flood, V.M. et al. (2018), "Healthiness of food and beverages for sale at two public hospitals in new South Wales, Australia", Nutrients, Vol. 10, No. 2. http://dx.doi.org/10.3390/nu10020216.

Wilson, W.W. and Dahl, B.L. (2011), "Grain contracting strategies: the case of durum wheat", Agribusiness, Vol. 27, No. 3, pp. 344-59.

Woojung, C. and Taylor, S. A. (2016), "The Effectiveness of customer participation in new product development: a meta-analysis, Journal of Marketing, Vol. 80, No. 1, pp. 47-64.

Yu, Y., Cao, R.Q. and Schniederjans, D. (2017), "Cloud computing and its impact on service level: a multiagent simulation model", International Journal of Production Research, Vol. 55, No. 15, pp. 4341-53.

Yunus, E.N. (2018), "Leveraging supply chain collaboration in pursuing radical innovation", International Journal of Innovation Science, Vol. 10, No. 3, pp. 350-70.

Zhai, Y., Zhong, R.Y., Li, Z. et al. (2017), "Production lead-time hedging and coordination in prefabricated construction supply chain management", International Journal of Production Research, Vol. 55, No. 14, pp. 3984-4002.

Authors contributions: Jeremias Araújo - Data Collection, Writing, Data Analysis; Paulo Sergio Gonçalves de Oliveira - Project Management, data analysis, Text Revision; Alexandre Faro Kaperaviczus - Writing, Text Revision, Data Analysis; Luciano Ferreira da Silva - Writing, Text Revision; Fabio Airton Bandero - Data Collection, Text Revision. 